\title{
ASSESSMENT OF TOURISTS' PERCEPTION AND SATISFACTION IN AGODI PARK AND GARDENS IBADAN AS A NATURE-BASED TOURISM ATTRACTION
}

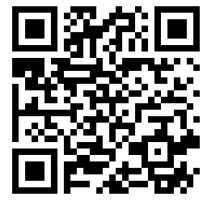

\author{
Operinde Olayinka Helen ${ }^{1}$, Emma-Egoro Praise ${ }^{*} 2 \llbracket$ \\ ${ }^{1}$ Centre for Sustainable Development, University of Ibadan, Oyo State, Nigeria \\ ${ }^{* 2}$ Department of Leisure and Tourism Management, Yaba College of Technology, Lagos State, \\ Nigeria
}

DOI: https://doi.org/10.29121/granthaalayah.v8.i7.2020.653

Article Type: Research Article

Article Citation: Operinde Olayinka Helen, and Emma-Egoro Praise. (2020). ASSESSMENT OF TOURISTS' PERCEPTION AND SATISFACTION IN AGODI PARK AND GARDENS IBADAN AS A NATURE-BASED TOURISM ATTRACTION. International Journal of Research GRANTHAALAYAH, 8(7), 144-159. https://doi.org/10.29121/granthaa layah.v8.i7.2020.653

Received Date: 05 July 2020

Accepted Date: 28 July 2020

Keywords:

Tourism

Tourist Satisfaction

Nature-Based Tourism Attraction

\section{ABSTRACT}

This study hinges on the assessment of tourists perception and satisfaction in Agodi Park and Gardens Ibadan as a nature-based tourism attraction. The study was conducted to investigate and assess the level of tourist's satisfaction with the attributes (facilities and services) at the Park. In order to achieve the aim of this study, a well-structured questionnaire was drafted in line with the research objectives. The findings of the study revealed that the most satisfying features at the Park was the natural environment and the swimming pool at $62.8 \%$ and $34.9 \%$ respectively. However, the most dissatisfying features were the Zoo (54.6\%) and the inadequate recreational facilities (17.4). The results also shows that the quality of tourism services has a positive impact on the level of tourist satisfaction. These results are considered to be valuable to destination managers, tourism organizations and businesses in evaluating the level of their current services. Therefore, this study suggests that visitors' satisfaction can be boosted by raising the standard of service quality throughout the destinations' attractions, facilities and modes of accessibility. The Parks' management should upgrade the zoological garden to meet up with International standard so as to increase tourists' patronage and satisfaction.

\section{INTRODUCTION}

Ecotourism is noted for preservation and conservation of the natural environment. Generally, it involves the travel to an undisturbed natural environment or destination where flora, fauna and other recreational facilities are the main attractions that makes tourist stay worthwhile and memorable. The major goal of ecotourism is to reveal to tourists the impact of human beings on the environment, and to encourage a greater appreciation of the natural environment (Adedeji and Fadamiro, 2014). These natural areas include national parks, zoological gardens, sanctuaries, forest reserves, game reserves etc. The national parks and zoological gardens give tourists an opportunity to visit, appreciate and enjoy parks rich in flora and fauna (Alarape et al, 2015).

Ecotourism, usually a form of nature-based tourism has been reported in the last decades as the latest trend in the tourism industry (Kukoyi, 2013). It is often claimed to be one of the fastest growing segments of the tourism market, with countries of Africa and beyond benefitting enormously from the sub- sector (Alarape et al, 2015). Within Africa, the countries that have fully developed their ecotourism potentials as a major source of foreign

(C) 2020 The Author(s). This is an open access article distributed under the terms of the Creative Commons Attribution License, which permits unrestricted use, distribution, and reproduction in any medium, provided the original author and source are credited. 
exchange earnings receiving the highest share of tourist traffic and revenue year in year out are Namibia, Kenya, Zimbabwe, Mozambique, Mauritius, Cape Verde, Botswana and the host of others.

Nigeria is endowed with rich and abundant tourism resources ranging from cultural to ecotourism attractions scattered all over the country. Some of the ecotourism attractions deposited in Nigeria are; Obudu mountain resort, Ikogosi warm spring, Gurrara waterfalls, Erin-Ijesa waterfalls, Idanre hills, Osun sacred forest groves, Sukur, Ogunike cave, Enemabia Warm Spring, Kainji lake national park, cross-river national park, Okomu national park, Kamuku national park, Agodi park and gardens and so on. Despite the numerous tourism resources that Nigeria possesses, the country still struggles to achieve her full tourism potentials. Uloko and Iwar, (2011); Omonona and Kayode, (2011) confirmed this in their study which observed that parks, zoological gardens and other tourism resources in Nigeria have the potentials of attracting tourists especially in nature-based tourism but their level of development, low tourist patronage and poor managerial strategies are the major factors affecting its growth.

In Oyo state, there are various nature-based attractions or centers which includes, Agodi Park and Gardens, University of Ibadan zoological Garden, Old Oyo National Park, Ado-Awaye Hanging Lake, and so on. Amongst the aforementioned attractions, Agodi Park and Gardens stands out because of its unique features. The tourist attraction hosts an indigenous forest rich in exotic flora, tree plantations, and lake. This particular attraction seems to have been the most favorable in terms of governments' attention in the area of renovation, development and promotion of tourism in Oyo state especially during the administration of Late former Governor Abiola Ajimobi.

The desire of any country is to develop and market their tourism industry because of the socio-economic benefits to be derived. With the growing competition in the global tourism industry, tourism operators and governments are searching for new strategies to increase their domestic and international tourist arrivals. Hence, increased competition for tourist arrival has been a major concern by many countries, cities and tourism establishments to specialize in developments that will give them a comparative advantage over their competitors (Suleyman et al, 2011). Therefore, the only way to achieve this is to engage in practices that will enhance marketing image and depict a destination as distinctive and unique (Pawitra and Tan, 2003).

One of the key measures to determine if tourism attractions are fulfilling the needs of tourists or not is the level of customer (tourist) satisfaction. The evaluation of tourist satisfaction allows tourism operators and destination managers to modify strategies to improve their productivity and increase the satisfaction of tourists. Thus, tourist satisfaction is assumed as one of the major elements of a distinctive tourism image, its successful management and growth, as it influences the selection of destination and the decision to revisit (Yoon and Uysal, 2005). Yooshik and Muzaffer (2003) also affirms that satisfaction plays an important role in planning marketable tourism products and services. Similarly, Dmitrovic et al (2009) supports that "enhancing tourist satisfaction should be one of the primary functions of any tourism attraction and a prerequisite for the development of a strategy leading to a destination enhanced attractiveness and its competitive positioning." In addition, a study by Choi \& Chu (2001) concludes that tourist satisfaction is seen as a post-consumption evaluation of an alternative cause of action in order to determine whether or not it meets or exceeds expectations. Chen \& Tsai (2007) pointed out that destination image, tourist expectation and perceived value are the major influences of tourist satisfaction. Tourism image which is an individual's mental representation of the knowledge, feelings, and overall perception of a particular tourist attraction, has been frequently proven to have direct effect on tourist behavior in terms of tourists expectation and perceived value.

The perception of tourists about a destination influences their satisfaction because when they perceive that the quality of services given to them is greater than the money paid, satisfaction is created (Chen et al, 2010). Yoon et al (2005) suggests that to measure the progress of any tourism outfit, the assessment of tourist satisfaction must be a basic parameter used to evaluate the performance of a destination and must play a significant role in planning marketable tourism products and services for the destination.

Tourists satisfaction is one of the most researched topics in this field because of the singular fact that tourists' satisfaction is crucial to the survival of any tourism attraction (Gursoy et al, 2003; 2007; Neal \& Gursoy, 2008), playing a significant role in tourists' decisions to recommend a place to others and revisit the sites (Kozak \& Rimmington, 2000). There is an apperception that if visitors are not happy with the performance of one or more components of the tourists' destination, it is very likely that their overall satisfaction would be affected (Pizam, Neumann \& Reichel, 1978). The general agreement is that visitors' overall satisfaction is a multidimensional construct based on the interaction between tourists and the elements at the tourism site. 
Scholars have suggested that when studying overall tourists' satisfaction, it is important to examine factors related to both the attraction and the services provided (Kozak \& Rimmington, 2000; Whipple \& Tach, 1988). Thus, the analysis of satisfaction in tourism has a dual purpose which is to provide information about tourists' needs in order to determine how well the organization or product is currently meeting those needs, and also to provide a platform for organizations to communicate with their customers to find out their likes, dislikes and overall satisfaction.

The subject of this research is based on the study of Agodi Parks and Gardens as a nature-based tourist attraction. The basic factors in the promotion of this Park are beautiful scenery and natural endowments, rich cultural heritage from various eras, and many other components. Accordingly, the purpose of this research paper is to assess tourist satisfaction with the facilities available and services rendered at this Park, explaining the perception of tourists which emanates from their experiences at the Park and in choosing Agodi Gardens as their destination. This research paper also points out the elements that need to be taken into consideration, as well as actions that need to be taken in order to ensure maximum tourist satisfaction at a tourist destination.

Agodi Park and Gardens was created as a nature-based tourist center in 1967 and managed by the western region then. It was formerly called Agodi Zoological and Botanical Gardens and was a top-notch relaxation center to provide recreational as well as educational services for residents and visitors. Unfortunately, the attraction lost its glory in 1980 due to a flood disaster that destroyed and swept away most of the gardens' wild animals and exotic vintage plants. As a result of this incident, people were left with little or nothing to look up to at the center and expectedly, the level of tourist's patronage dropped drastically.

After so many years of abandonment, the Park and Gardens was renovated in 2012 under the late former Governor Abiola Ajimobi led-administration and was officially re-opened in 2014. Since then, the attraction has been experiencing constant inflow of tourist arrivals. Due to this tremendous change, the researcher opines that there is a need to access the level of tourist satisfaction with the recent facilities and services provided at the attraction.

As laudable as this task may be, there is little or no existing study known to the researchers directed towards the perception and satisfaction of tourists at Agodi Park and Gardens. It is on this basis that this present study focuses on assessing the tourists' perception, satisfaction in Agodi Park and Gardens as a nature-based attraction.

The aim of this study was to assess the level of tourist satisfaction with the services and facilities of Agodi Parks and Gardens. This aim was achieved through the following objectives;

1) Understanding the socio-demographic characteristics of tourists who visit Agodi Parks and Gardens.

2) Examining the perception of tourist on the attributes (facilities and services) of Agodi Park and Gardens as related to their satisfaction.

3) Identifying those aspects/areas the tourists are not satisfied with at this attraction.

4) Suggesting appropriate measures to improve the effectiveness of this tourist center and enhance tourist's satisfaction.

It is expedient to state that this research will contribute to the understanding and documentation of tourists' perception and the overall level of their satisfaction with the facilities and quality of services rendered at Agodi Park and Gardens. Also, investigating the satisfaction of tourists will most importantly assist the Oyo state government and tourism managers to identify those aspects that need improvement so as to sustain this tourist center in order to encourage more patronage and enhance the satisfaction of tourists to the maximum level.

\section{STUDY AREA}

Agodi Parks and Gardens is located at Agodi, Ibadan north local government area of Oyo state. It occupies about 13 acres (approximately 5.3 hectares) of land. The geographical coordinates are Latitude $7024^{\prime} 25^{\prime \prime} \mathrm{N}$ and Longitude 30 53' 57"E with an elevation of $191 \mathrm{~m}$ above sea level. The tropical climate of Ibadan in which the garden is situated provides a moderate and optimal weather for the relaxation. This park and gardens is best described as an epitome of peace because of the abundance of trees surrounding it. The park provides an opportunity for nature lovers to enjoy the scenic view of nature at its peak. It also offers various recreational facilities to keep the tourists engaged while at the park. The park is usually patronized by tourists during public holidays, festive periods and weekends. The facilities available at Agodi parks and gardens are as follows;

- Restaurant and bar 
- Concession stands

- Swimming pool and water park

- Children's play area

- Park benches

- Mini zoo

- Horse riding and bicycling

- Wash rooms and convenience

- 50-car parking lot

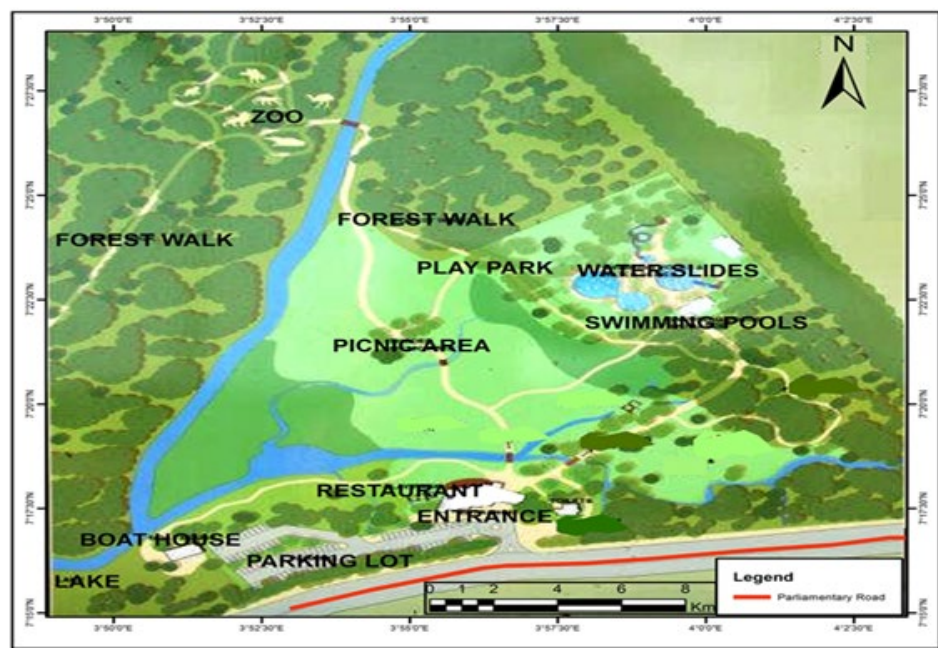

Figure 1: Map of Agodi Park and Gardens

Source: Authors' survey 2019

Other features include open lush-green space for picnics and small events, an artificial lake which contributes to the beauty of the park, walkways, and indigenous tree species.

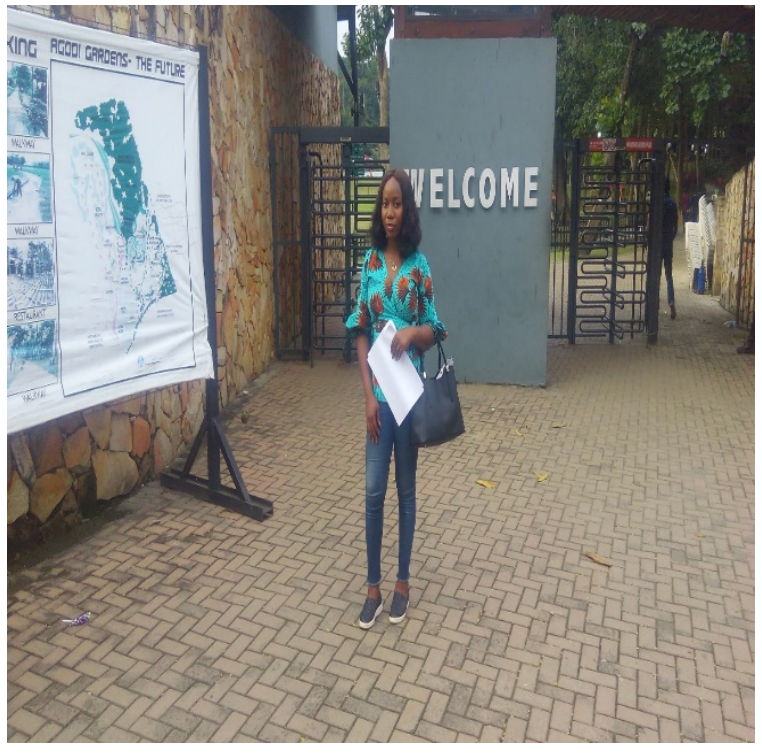

Plate 1: The main entrance of Agodi Gardens Source: Authors' field survey 2019

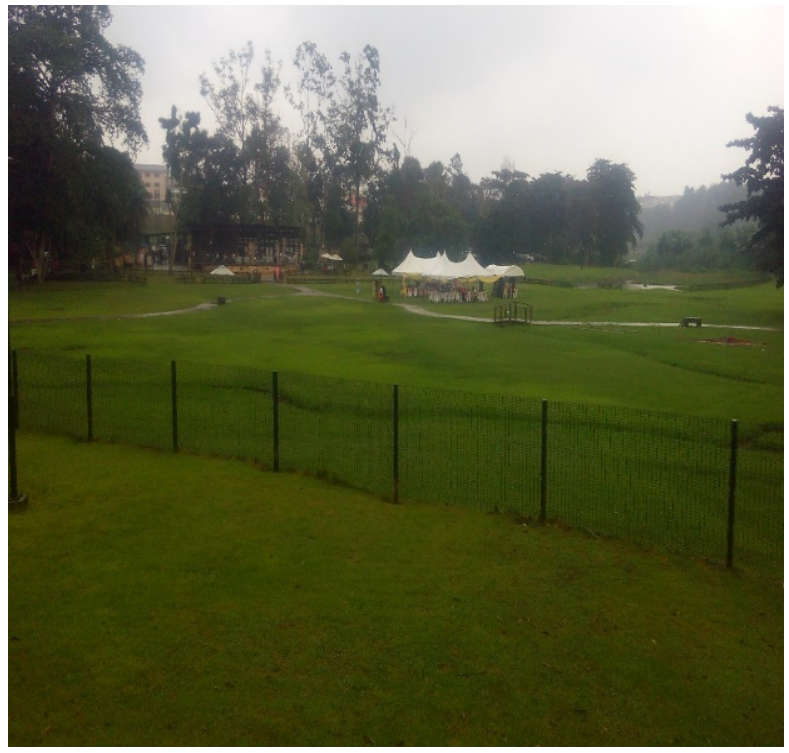

Plate 2: Ongoing event on the lush-green area of the park Source: Authors' field survey 2019 


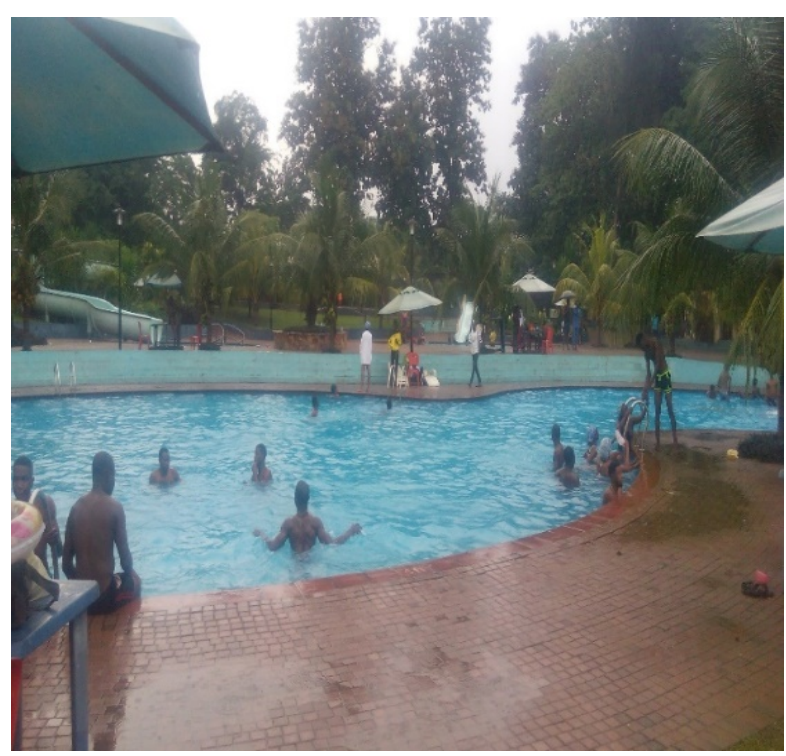

Plate 3: The Waterpark area

Source: Authors' field survey 2019

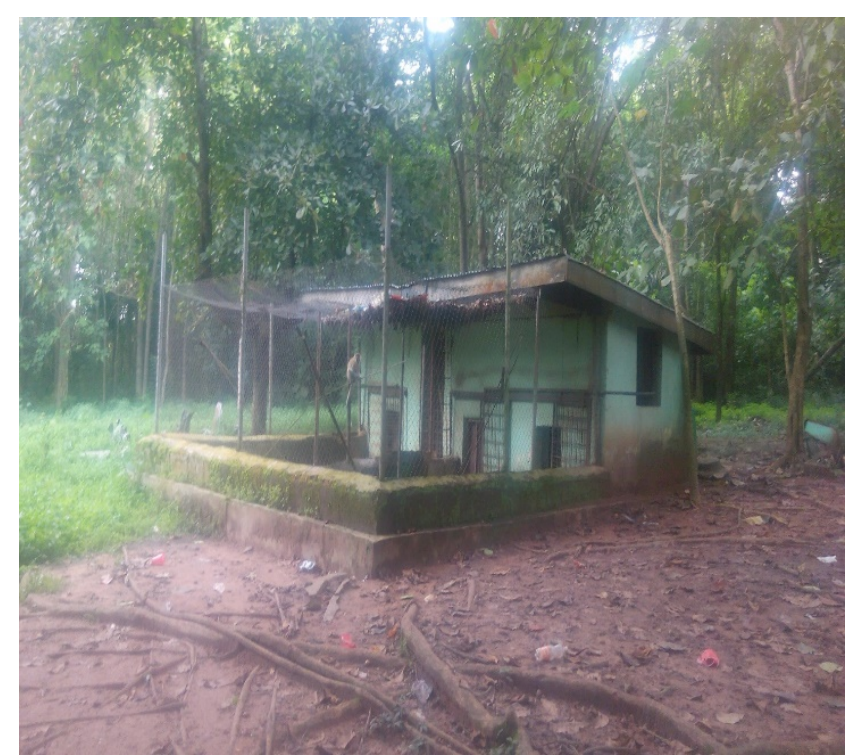

Plate 4: Poor Animal Enclosure at the Zoo Source: Authors' field survey 2019

\section{MATERIALS AND METHODS}

The research was conducted using a survey design. The target population for this study was mainly the visiting tourists at Agodi Park and Gardens. Prior to the survey, the researchers studied the influx of tourists into the Park for four weeks due to the dearth of statistical data on tourist flow at the park. From the observation, it was gathered that approximately 1000 tourists visit the Park weekly and this formed the population of the study. Convenience sampling was adopted as the sampling technique for administering the structured questionnaires to the tourists at the Park. Adopting 20\% of the total estimated tourists' population at the Park, which is 1000, the sample size for this study was 200 tourists. Out of the 200 questionnaires distributed, 181 were retrieved. Out of the 181 questionnaires returned, 9 were void, making it a total of 172 valid questionnaires. The data obtained from the survey was analyzed using the statistical package for social sciences (SPSS) 2016. Descriptive statistical tools such as frequencies, percentages, mean, standard deviation, tables, charts/graphs was used to analyze and present the data collected. The hypotheses were tested using multiple regressions for relationships and analysis of variance (ANOVA) for mean difference.

\section{RESULT AND DISCUSSION}

Table 4.1a: Demographic Characteristics of the Respondents

\begin{tabular}{|c|c|c|c|c|}
\hline S/N & Variables & Status & Frequency & Percent \\
\hline 1. & Gender & Male & 84 & $48.8 \%$ \\
\hline & & Female & 88 & $51.2 \%$ \\
\hline & & Total & 172 & $100 \%$ \\
\hline 2. & Age & Below 20 Years & 12 & $7 \%$ \\
\hline & & $21-30$ Years & 90 & $52.3 \%$ \\
\hline & & $31-40$ Years & 38 & $22.1 \%$ \\
\hline & & $41-50$ Years & 26 & $15.1 \%$ \\
\hline & & 50 Years and above & 6 & $3.5 \%$ \\
\hline & & Total & 172 & $100 \%$ \\
\hline 3. & Marital Status & Married & 70 & $40.7 \%$ \\
\hline & & Single & 94 & $54.7 \%$ \\
\hline & & Divorce/Separated & 8 & $4.7 \%$ \\
\hline & & Total & 172 & $100 \%$ \\
\hline
\end{tabular}


Assessment of Tourists' Perception and Satisfaction in Agodi Park and Gardens Ibadan as A Nature-Based Tourism Attraction

\begin{tabular}{|c|c|c|c|c|}
\hline \multirow{6}{*}{4.} & Educational Status & Secondary & 14 & $8.1 \%$ \\
\hline & & Honors & 94 & $54.7 \%$ \\
\hline & & Masters & 34 & $19.8 \%$ \\
\hline & & $\mathrm{PhD}$ & 2 & $1.2 \%$ \\
\hline & & Others & 28 & $16.3 \%$ \\
\hline & & Total & 172 & $100 \%$ \\
\hline \multirow[t]{6}{*}{5.} & Occupation & Student & 38 & $22.1 \%$ \\
\hline & & Teacher & 8 & $4.7 \%$ \\
\hline & & Civil Servant & 22 & $12.8 \%$ \\
\hline & & Self Employed & 54 & $31.4 \%$ \\
\hline & & Others & 50 & $29.1 \%$ \\
\hline & & Total & 172 & $100 \%$ \\
\hline \multirow[t]{7}{*}{6.} & Average Monthly Income & Below $¥ 20,000$ & 16 & $9.3 \%$ \\
\hline & & $\mathrm{N} 21,000-\$ 40,000$ & 38 & $22.1 \%$ \\
\hline & & $\$ 41,000-\$ 60,000$ & 34 & $19.8 \%$ \\
\hline & & $\mathrm{N} 61,000-\mathrm{N} 80,000$ & 12 & $7 \%$ \\
\hline & & $\mathrm{N} 81,000-\mathrm{N100,000}$ & 14 & $8.1 \%$ \\
\hline & & $\$ 101,000$ and above & 58 & $33.7 \%$ \\
\hline & & Total & 172 & $100 \%$ \\
\hline
\end{tabular}

Source: Author's Field Survey, 2019

Table 1b: Factors Influencing Tourist Visit to Agodi Parks and Gardens

\begin{tabular}{|c|c|c|c|c|}
\hline $\mathrm{S} / \mathrm{N}$ & Statement & Responses & Frequency & Percent \\
\hline 1. & \multirow{3}{*}{$\begin{array}{l}\text { How did you arrive at Agodi } \\
\text { Parks and Garden? }\end{array}$} & Private Vehicle & 92 & $54.5 \%$ \\
\hline & & Public Transport & 80 & $46.5 \%$ \\
\hline & & Total & 172 & $100 \%$ \\
\hline \multirow[t]{6}{*}{2.} & \multirow{2}{*}{$\begin{array}{l}\text { Where did you hear about this tourist } \\
\text { attraction? }\end{array}$} & I stumbled on it & 24 & $14 \%$ \\
\hline & & The internet & 34 & $19.8 \%$ \\
\hline & & Friends and relatives & 110 & $64 \%$ \\
\hline & & Media & 2 & $1.2 \%$ \\
\hline & & Books and Guides & 2 & $1.2 \%$ \\
\hline & & Total & 172 & $100 \%$ \\
\hline \multirow[t]{3}{*}{3.} & \multirow[t]{3}{*}{ Is this your first visit to this attraction? } & Yes & 58 & $33.7 \%$ \\
\hline & & No & 114 & $66.3 \%$ \\
\hline & & Total & 172 & $100 \%$ \\
\hline \multirow[t]{4}{*}{4.} & \multirow{3}{*}{$\begin{array}{l}\text { How many times have you visited this attraction } \\
\text { in the past? }\end{array}$} & Two times & 52 & $30.2 \%$ \\
\hline & & Three times & 22 & $12.8 \%$ \\
\hline & & Four times and more & 40 & $23.3 \%$ \\
\hline & & Total & 172 & $100 \%$ \\
\hline \multirow[t]{5}{*}{5.} & \multirow{2}{*}{$\begin{array}{l}\text { What are the features that attracted you to } \\
\text { Agodi Parks and Gardens? }\end{array}$} & The natural environment & 112 & $65.1 \%$ \\
\hline & & $\begin{array}{l}\text { The level and quality of facilities } \\
\text { at the park }\end{array}$ & 20 & $11.6 \%$ \\
\hline & & All of the above & 46 & $26.7 \%$ \\
\hline & & Others & 4 & $2.3 \%$ \\
\hline & & Total & 172 & $100 \%$ \\
\hline 6. & & & 60 & $34.9 \%$ \\
\hline
\end{tabular}


Operinde Olayinka Helen, and Emma-Egoro Praise

\begin{tabular}{|c|c|c|c|c|}
\hline \multirow{2}{*}{$\begin{array}{c}\text { What are the main reasons for your visit to this } \\
\text { attraction? }\end{array}$} & $\begin{array}{c}\text { Enjoy natural and aesthetic } \\
\text { beauty }\end{array}$ & \\
\cline { 3 - 5 } & & Rest and relaxation & 70 & $40.7 \%$ \\
\hline & & Sport and recreation & 20 & $11.6 \%$ \\
\hline & & Events & 12 & $7 \%$ \\
\hline & & Business & 4 & $2.3 \%$ \\
\hline & & Besearch and Education & 2 & $1.2 \%$ \\
\hline & & Total & 4 & $2.3 \%$ \\
\hline
\end{tabular}

Source: Author's Field Survey, 2019

\section{TOURISTS ACCOMPANIED BY}

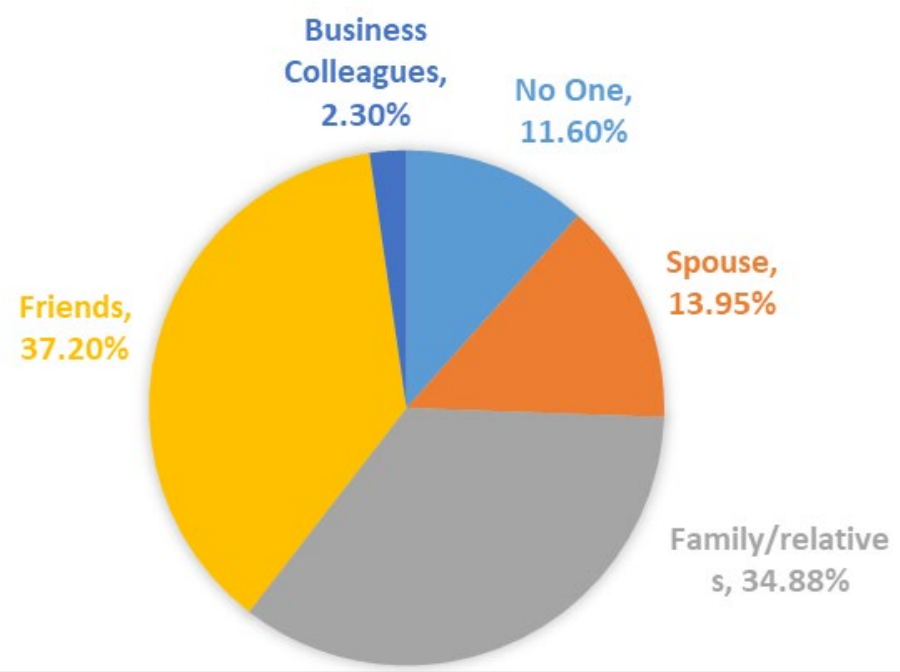

Figure 2: groups of people who accompanied tourists to Agodi Park and Gardens Source: Author's Field Survey, 2019

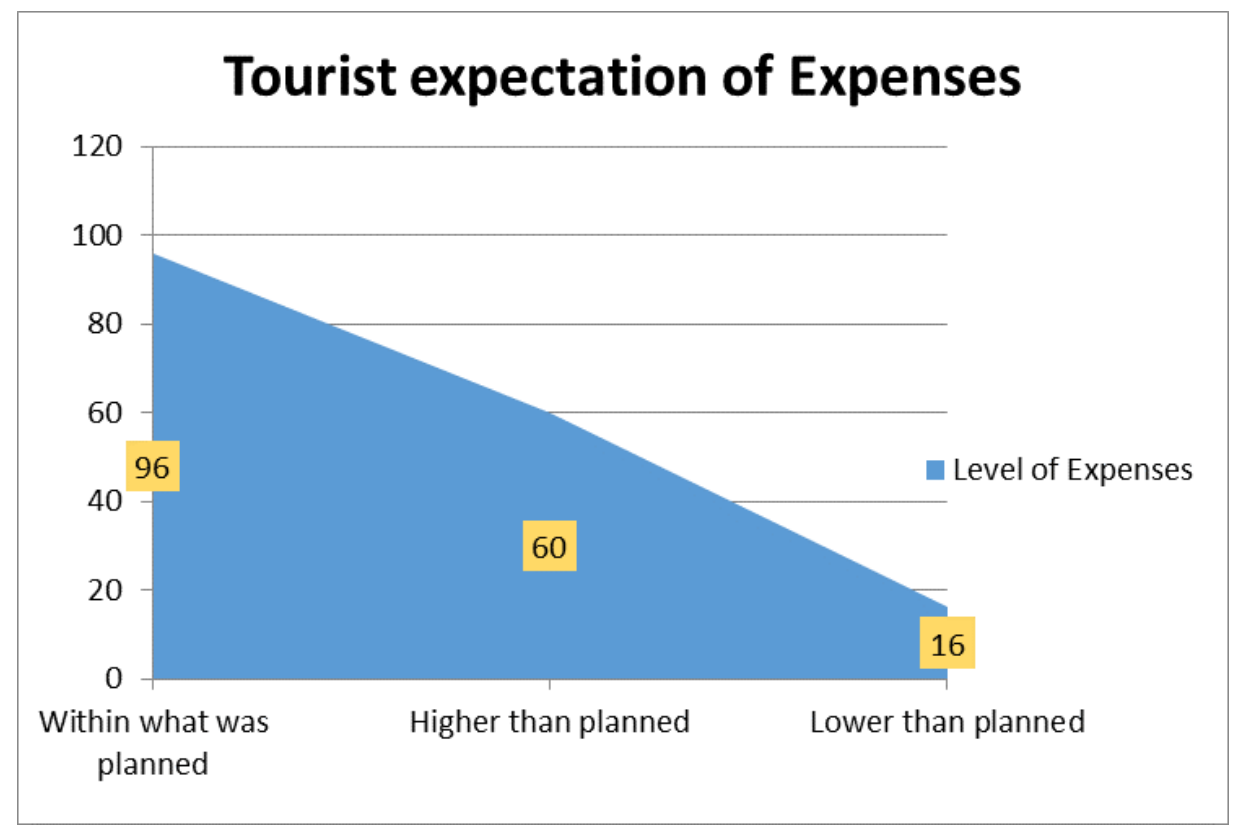

Figure 3: Tourist expectation of expenses in relations to their budget at Agodi Gardens Source: Author's Field Survey, 2019 


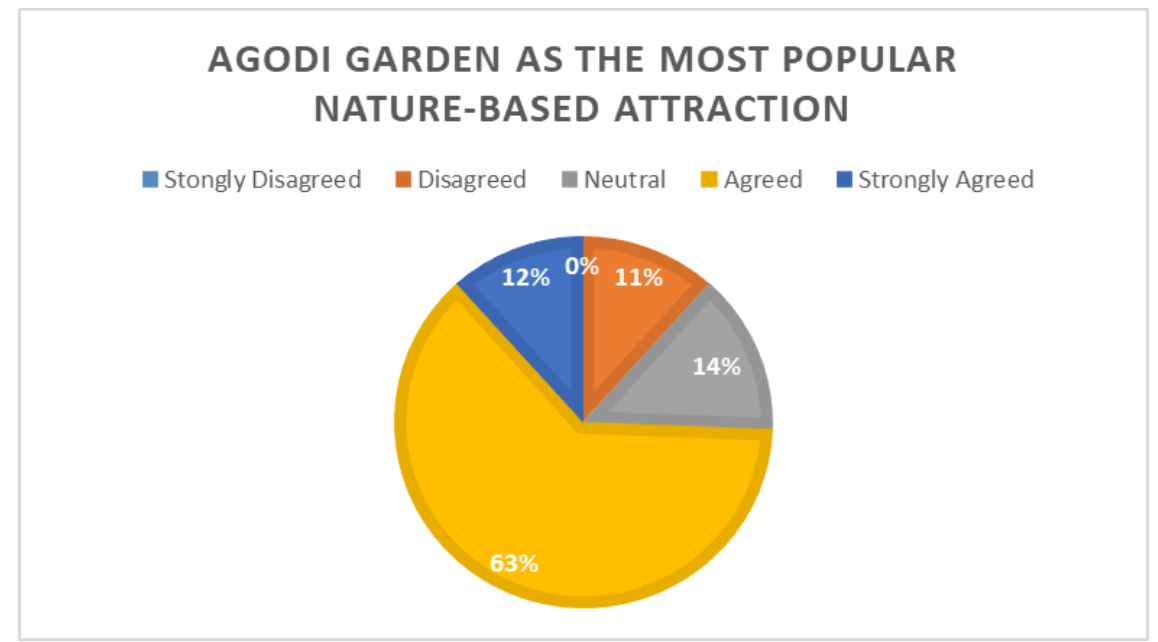

Figure 4: Agodi Gardens as the most popular nature-based attraction in Ibadan Source: Author's Field Survey, 2019

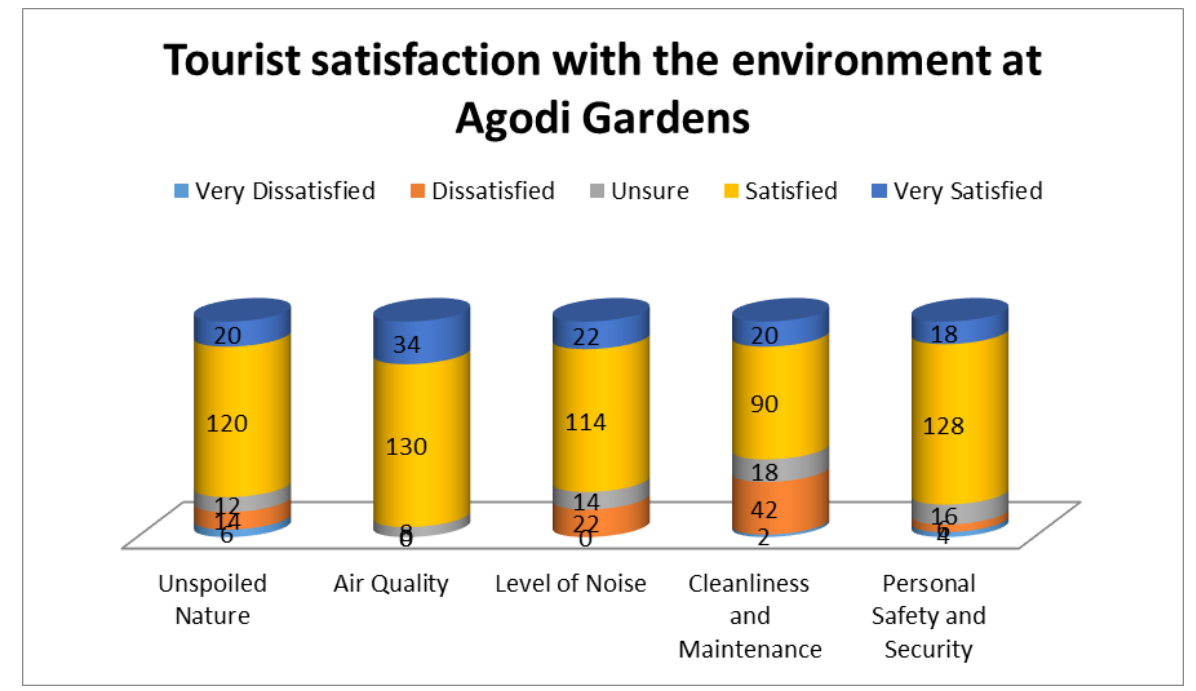

Figure 5: Tourists' Satisfaction with the Environment of Agodi Parks and Gardens Source: Author's Field Survey, 2019

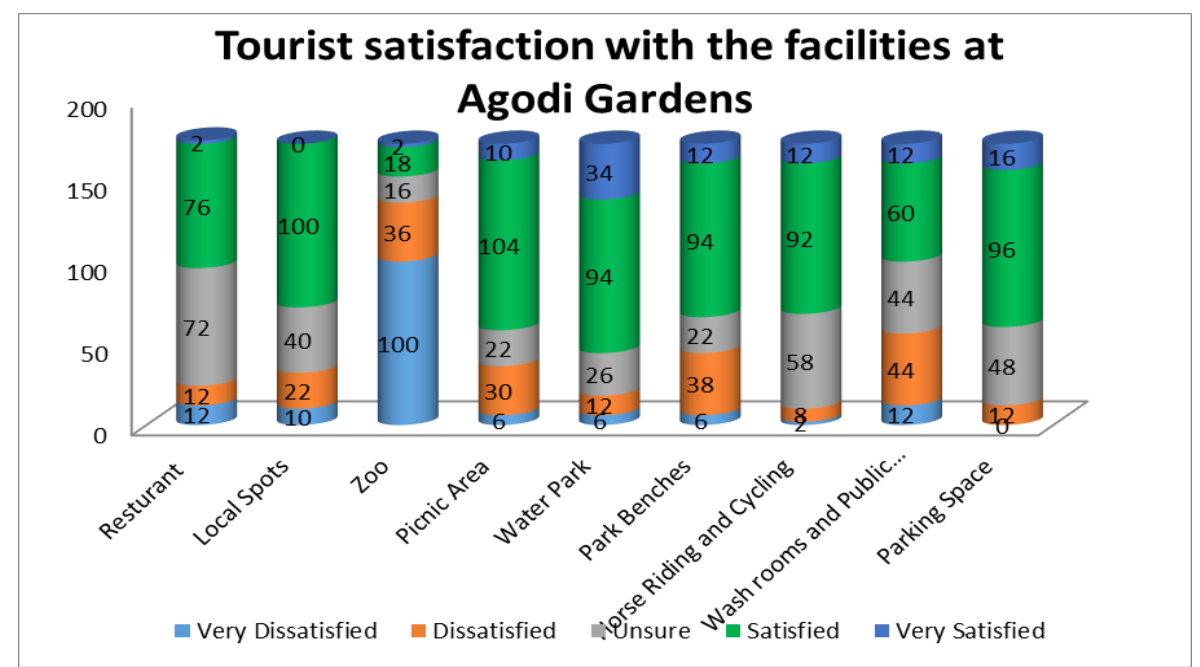

Figure 6a: Tourists' Satisfaction with the Facilities of Agodi Parks and Gardens Source: Author's Field Survey, 2019 


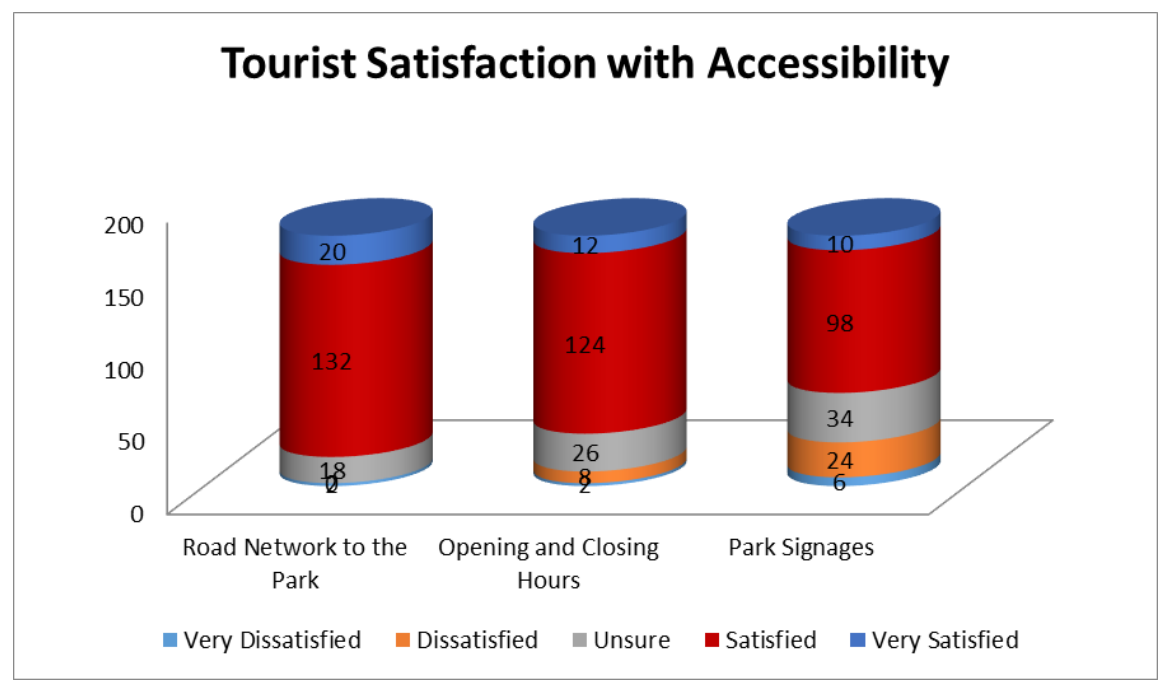

Figure 6b: Tourists' Satisfaction with Accessibility to Agodi Parks and Gardens Source: Author's Field Survey, 2019

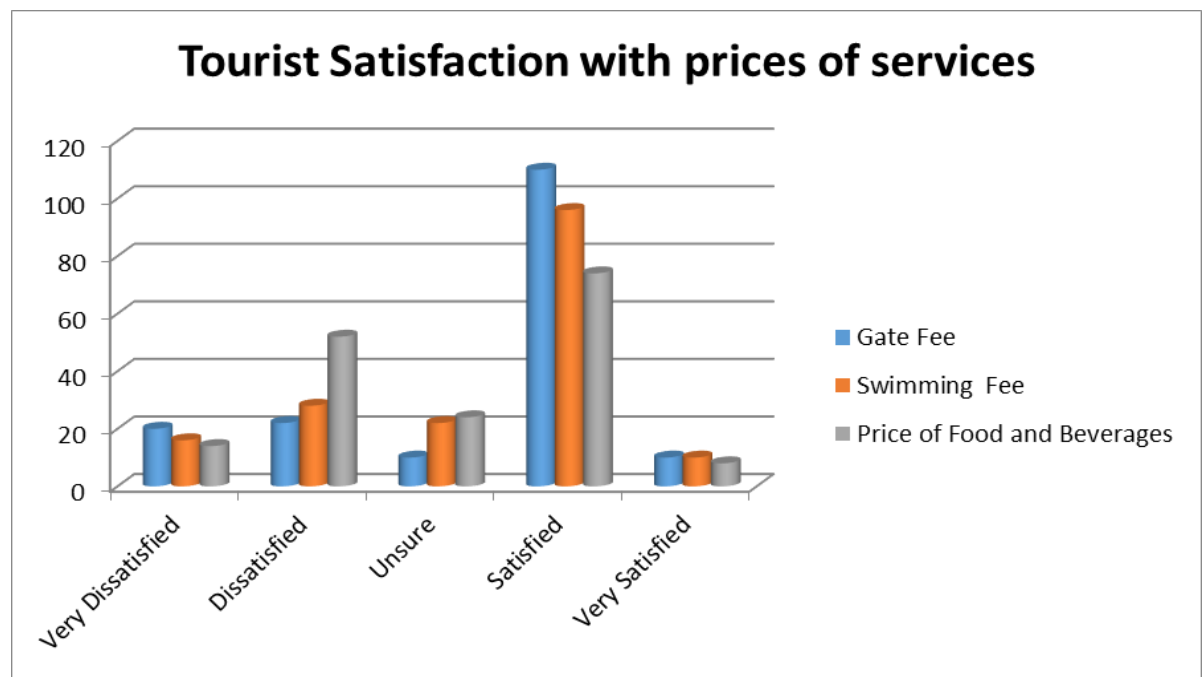

Figure 7: Tourists' Satisfaction with price of Products and Services at Agodi Gardens Source: Author's Field Survey, 2019

\section{Tourist Satisfaction with Service Quality}

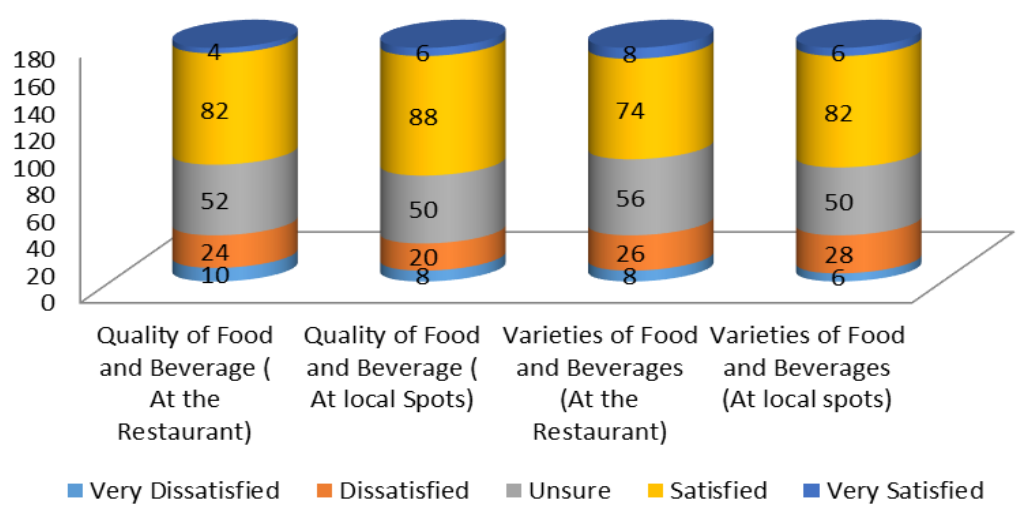

Figure 8: Tourists' Satisfaction with Services Quality at Agodi Parks and Gardens Source: Author's Field Survey, 2019 


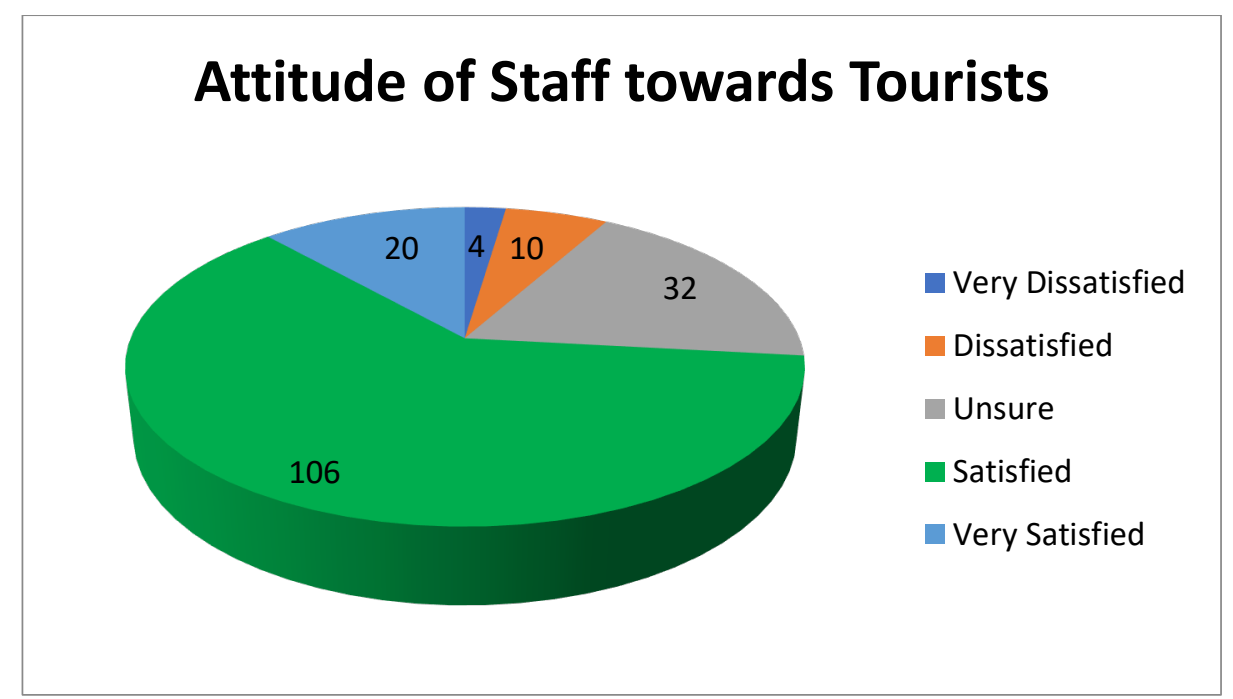

Figure 9: Attitude of Staff towards tourist at Agodi Parks and Gardens Source: Author's Field Survey, 2019

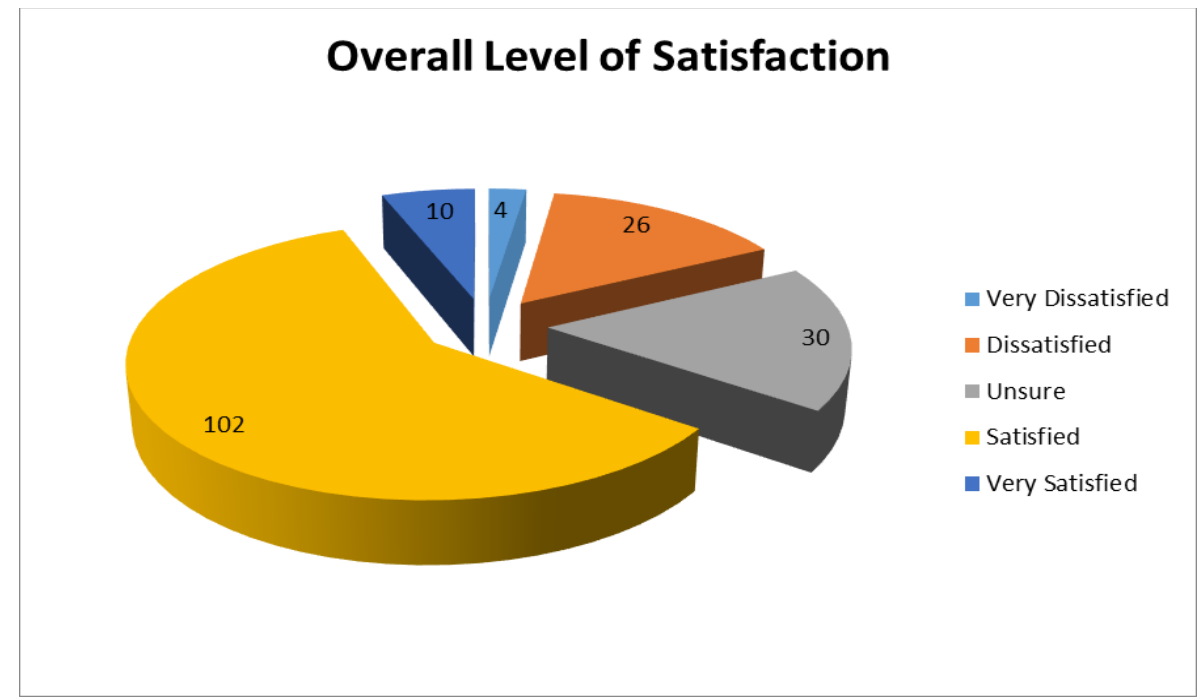

Figure 10: The Overall Level of Tourist Satisfaction at Agodi Parks and Gardens Source: Author's Field Survey, 2019

\section{Most Satisfying Attractions}

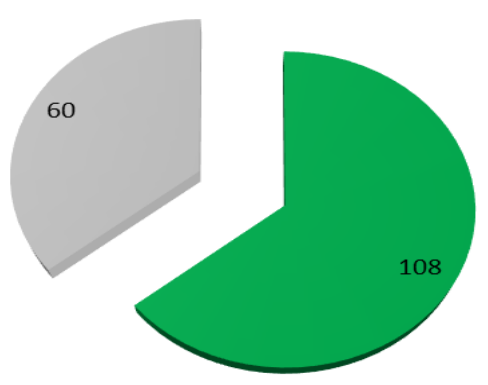

Natural Environment

- Swimming Pool

Figure 11: The Attractions that Tourist are most satisfied with at Agodi Gardens Source: Author's Field Survey, 2019 


\section{Dissatisfying Features}

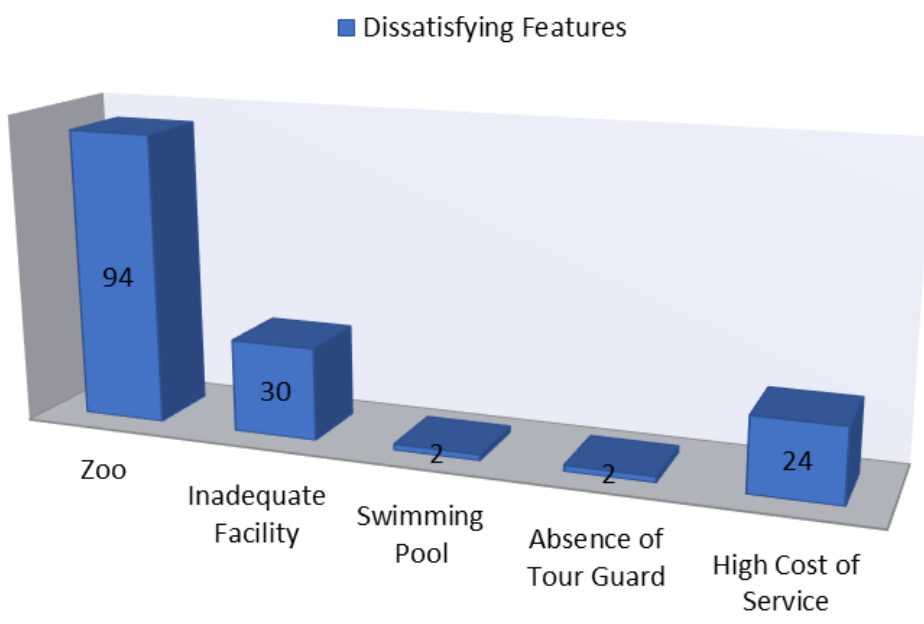

Figure 12: The Features that Dissatisfied Tourist Most at Agodi Parks and Gardens Source: Author's Field Survey, 2019

Table 2: Respondents' Intent to Recommend and Revisit Agodi Parks and Gardens

\begin{tabular}{|c|c|c|c|c|}
\hline $\mathrm{S} / \mathrm{N}$ & Statement & Responses & Frequency & Percent \\
\hline 1. & \multirow[t]{5}{*}{ The visit to Agodi Gardens exceeded my expectation } & Disagreed & 48 & $28 \%$ \\
\hline & & Neutral & 54 & $31.4 \%$ \\
\hline & & Agreed & 66 & $38.4 \%$ \\
\hline & & Strongly Agreed & 4 & $2.3 \%$ \\
\hline & & Total & 172 & $100 \%$ \\
\hline 2. & \multirow[t]{6}{*}{ I am pleased that I decided to visit this attraction } & $\begin{array}{c}\text { Strongly } \\
\text { Disagreed }\end{array}$ & 2 & $1.2 \%$ \\
\hline & & Disagreed & 14 & $8.1 \%$ \\
\hline & & Neutral & 56 & $32.6 \%$ \\
\hline & & Agreed & 86 & $50 \%$ \\
\hline & & Strongly Agreed & 26 & $15.1 \%$ \\
\hline & & Total & 172 & $100 \%$ \\
\hline \multirow[t]{6}{*}{3.} & \multirow[t]{6}{*}{$\begin{array}{c}\text { I will speak highly of Agodi Garden to my friends and } \\
\text { relatives }\end{array}$} & $\begin{array}{c}\text { Strongly } \\
\text { Disagreed }\end{array}$ & 2 & $1.2 \%$ \\
\hline & & Disagreed & 18 & $10.5 \%$ \\
\hline & & Neutral & 42 & $24.4 \%$ \\
\hline & & Agreed & 96 & $55.8 \%$ \\
\hline & & Strongly Agreed & 14 & $81 . \%$ \\
\hline & & Total & 172 & $100 \%$ \\
\hline \multirow[t]{5}{*}{4.} & \multirow{5}{*}{$\begin{array}{l}\text { I will recommend this tourist } \\
\text { attraction to my friends and } \\
\text { relatives }\end{array}$} & Disagreed & 16 & $9.3 \%$ \\
\hline & & Neutral & 44 & $25.6 \%$ \\
\hline & & Agreed & 98 & $57 \%$ \\
\hline & & Strongly Agreed & 14 & $8.1 \%$ \\
\hline & & Total & 172 & $100 \%$ \\
\hline \multirow[t]{2}{*}{5.} & I will revisit this attraction & $\begin{array}{c}\text { Strongly } \\
\text { Disagreed }\end{array}$ & 4 & $2.3 \%$ \\
\hline & & Disagreed & 14 & $8.1 \%$ \\
\hline
\end{tabular}


Assessment of Tourists' Perception and Satisfaction in Agodi Park and Gardens Ibadan as A Nature-Based Tourism Attraction

\begin{tabular}{|c|c|c|c|c|}
\hline & Neutral & 26 & $15.1 \%$ \\
\hline & Agreed & 104 & $60.5 \%$ \\
\hline & & Strongly Agreed & 24 & $14 \%$ \\
\hline & Total & 172 & $100 \%$ \\
\hline
\end{tabular}

Source: Author's Field Survey, 2019

The visitors' characteristics of interest to this study are the age, gender, marital status, educational qualification, occupation and level of income. The study examined whether the tourists were first-time or recurrent visitors [see Table 1b]. 66.3\% of the respondents were recurrent visitors, 35.7\% were first-time visitors. Agodi Park and Gardens is an attraction at the heart of the ancient city of Ibadan, it pulls visitors from both the length and breadth of this city and most people tend to visit for one reason or another, with or without company. Fig. 2 shows that $37 \%$ of the respondents visited the Park with their friends, 35\% came with relatives, others with their spouses and some others with their business colleagues. The Park and Gardens offers the tourist an escape from the hustle and bustle associated with regular city life, and provides few varieties of outdoor recreational activities in which visitors can participate in to relieve stress.

Agodi Park and Gardens is highly patronised mostly by youth and young couples between the ages 21-30 (52.3\%) [Table 1a] and most of them arrive in their private vehicles [Table 1b]. A large portion of the respondents stated that they heard about the Park from friend and relatives (64\%) as seen in Table 1b, 65.1\% of them asserting that the natural environment is the most prominent feature of the park that attract people. $40.7 \%$ of the respondents claimed they visit the park for rest and relaxation purposes while $34.9 \%$ say they simply came to enjoy the natural and aesthetic beauty of the Park.

Majority of the respondents indicated that they expected their expenses at the Park to be within the range they have budgeted for their visit [Fig. 3]. However, some 34.9\% of the respondents expected their expense to go beyond the budget for their visit to the park. This is not surprising based on previous researches that suggested people eventually spend more at natural sites than other places of attraction due to their self-inclement to enjoy almost everything at the site (Chandler \& Costello, 2002). Although the gap between estimated budget and actual expenses of visitors at Agodi Gardens is not very wide. However, there is a very wide gap between visitors spending within their budgets and spending lower than budget as this could be explained by the fact that during festive periods and public holidays, a lot of families come to the park to engage in family activities such as picnics and other outdoor recreational activities. Most people have positive impression about Agodi Parks and Gardens because of its unique image as compared to other nature-based attractions in Ibadan. Many of the respondents agreed that Agodi Gardens is the most popular nature-based attraction in Ibadan [Fig. 4] and is strategically located in the city center.

In a research done by Oppermann (2007) on the characteristics of natural sites that were considered to be capable of attracting tourists; the environment and facilities at those sites, and the accessibility to the sites were the major highlighted features [Fig. 5]. An average of 80.9\% tourists at Agodi Gardens are grossly satisfied with the unspoiled nature and air quality along with the low-level of noise pollution, cleanliness and personal safety and security at the park. A further combined average of $23.54 \%$ are very dissatisfied with the facilities at Agodi Park and Gardens [Fig. 6a] most especially the parks' zoological garden (77.27\%). While majority of the respondents are satisfied with the Park's accessibility [Fig. 6b].

Additionally, the respondents are of the opinion that the tariff costs of services at the park are quite reasonable and affordable [Fig. 7]. However, in Fig. 8, the quality of service analysis at the park received mixed reactions from the respondents as $30 \%$ are not sure of the level of service and $14.2 \%$ are not so pleased with the services especially quality of food at both the concession stands and the restaurant. In the same vein, $14.2 \%$ of the respondents are dissatisfied with the absence of variety of food and beverages at the park. Meanwhile, the tourist feel at home with the staff of the park as $61.6 \%$ of the respondents are satisfied with the attitude of staff towards tourist [Fig. 9]. Overall, in Fig. 10, 59.3\% of the tourist are satisfied with the facilities and services at Agodi Gardens. The most satisfying features at Agodi Parks and Gardens to the tourists are the natural environment (62.8\%), and the swimming pool (34.9\%) [See Fig. 11]. However, the most dissatisfying features are zoo (54.6\%) and inadequate recreational facilities (17.4\%) [See Fig. 12].

Opinions were competitively divided when tourists submitted their view on the extent to which the Park met their expectations [see Table 2]. 38.4\% felt that their expectations were exceeded, $28 \%$ were of the opinion that the Park did not meet their expectation, $31.4 \%$ were neutral. Furthermore, $50 \%$ of the respondents were pleased to have 
visited Agodi Park and Gardens. 55.8\% opined that they will speak highly of the park to their friends and relatives. Another 57\% of the respondents stated that they will recommend Agodi Gardens while a significant $60.5 \%$ signified that they will revisit the attraction in the future. Robinson and Gammon (2004) argue that repeat tourists are different from first-time tourists in that those visiting a destination for the first time are looking to escape from an environment, while repeat visitors are looking to escape to an environment that they are familiar and comfortable with. Lastly, once visitors learn about the significance and importance of Agodi Gardens, the excitement is experiential and the environment is alluring; thus a more reason why people are willing to go back.

\section{REGRESSION ANALYSIS ON RESEARCH OBJECTIVES}

Table 4.5: Correlations between Features and Services of Agodi Parks and Garden and the Perception of Tourist about the Park

\begin{tabular}{|c|c|c|c|}
\hline & & $\begin{array}{c}\text { Attributes of Agodi Parks and } \\
\text { Gardens }\end{array}$ & $\begin{array}{c}\text { Perception of Tourist about the } \\
\text { Site }\end{array}$ \\
\hline \multirow[t]{3}{*}{$\begin{array}{l}\text { Tourists interest in the } \\
\text { Park }\end{array}$} & $\begin{array}{l}\text { Pearson } \\
\text { Correlation }\end{array}$ & 1 & -.212 \\
\hline & Sig. (2-tailed) & & .139 \\
\hline & $\mathrm{N}$ & 50 & 50 \\
\hline \multirow[t]{3}{*}{$\begin{array}{c}\text { Tourist patronage of the } \\
\text { park }\end{array}$} & $\begin{array}{l}\text { Pearson } \\
\text { Correlation }\end{array}$ & -.212 & 1 \\
\hline & Sig. (2-tailed) & .139 & \\
\hline & $\mathrm{N}$ & 50 & 50 \\
\hline
\end{tabular}

** Correlation is significant at the 0.01 level (2-tailed).

The correlation between the services/facilities of Agodi Gardens and the perception of tourist about the Park is 0.139 and it is not significant at level 1\%. Moreover, there is a negative relationship and this postulates that there is an indirect relationship between perception of tourist and the services/facilities of the Park. This implies that tourist visit Agodi Gardens regardless of what attracts them and the services/facilities at Agodi Gardens, this does not influence tourist patronage. Agodi Gardens is a heterogeneous ecotourism park with several attributes that can attract tourist. If tourists are not satisfied with one feature, they will be satisfied with another.

Table 4.6: Correlations between Services/facilities of Agodi Parks and Garden and the level of tourists' satisfaction

\begin{tabular}{|c|c|c|c|}
\hline & & $\begin{array}{c}\text { Attributes of Agodi Parks and } \\
\text { Gardens }\end{array}$ & $\begin{array}{c}\text { Level of Tourist } \\
\text { Satisfaction }\end{array}$ \\
\hline \multirow[t]{3}{*}{$\begin{array}{l}\text { Inadequate features and } \\
\text { attributes }\end{array}$} & $\begin{array}{c}\text { Pearson } \\
\text { Correlation }\end{array}$ & 1 & $.434^{* *}$ \\
\hline & Sig. (2-tailed) & & .002 \\
\hline & $\mathrm{N}$ & 50 & 50 \\
\hline \multirow[t]{3}{*}{ Level of tourist satisfaction } & $\begin{array}{c}\text { Pearson } \\
\text { Correlation }\end{array}$ & $.434^{* *}$ & 1 \\
\hline & Sig. (2-tailed) & .002 & \\
\hline & $\mathrm{N}$ & 50 & 50 \\
\hline
\end{tabular}

** Correlation is significant at the 0.01 level (2-tailed).

The correlation between inadequate facilities/services at the Park and level of tourist satisfaction with the Park is 0.002 and it is significant at level $1 \%$. Moreover, there is positive relationship and this signifies that there is direct relationship between inadequate service/facilities and tourist satisfaction. This implies that tourist will likely feel 
Assessment of Tourists' Perception and Satisfaction in Agodi Park and Gardens Ibadan as A Nature-Based Tourism Attraction

dissatisfied when their expectations for a particular facility or service is not met. At Agodi Gardens, tourist are mostly dissatisfied with the Zoological garden and the absence of variety of meals at the restaurant and concession stands.

\section{HYPOTHESIS TESTING}

H0: The satisfaction of tourist is not significantly dependent on the facilities and services rendered at Agodi Park and Gardens.

H1: The satisfaction of tourist is significantly dependent on the facilities and services rendered at Agodi Park and Gardens.

Table 4.9: Analysis of Variance (ANOVA) of service and facilities influence on tourist satisfaction

\begin{tabular}{|c|c|c|c|c|c|c|}
\hline \multicolumn{2}{|c|}{ Model } & Sum of Squares & Df & Mean Square & F & Sig. \\
\hline \multirow{2}{*}{1} & Regression & .194 & 19 & .194 & .948 & $.335 \mathrm{a}$ \\
\cline { 2 - 8 } & Residual & 9.806 & 153 & .204 & & \\
\cline { 2 - 8 } & Total & 10.000 & 172 & & & \\
\hline
\end{tabular}

Predictors: (Constant), facilities and services affect tourist satisfaction.

Dependent Variable: Tourist satisfaction

The regression and residual sums of squares are not equal, which implies that tourists may feel satisfied with some features of the Park over others, however, the overall level of satisfaction is affected by the facilities and services provided as indicated in the model. The significance value of the F statistic is greater than $5 \%$.

DECISION RULE: Accept $\mathrm{H} 1$ if $\mathrm{P}$-value is greater than 0.05 , reject $\mathrm{H} 0$ if otherwise

CONCLUSION: Since the $\mathrm{P}$ - value is 0.335 and is greater than 0.05 we rejects $\mathrm{H} 0$, we therefore accept $\mathrm{H} 1$ and conclude that facilities and services at Agodi Gardens affect tourist overall satisfaction of the Park by the respondent at 0.05 level of significance.

\section{CONCLUSION AND RECOMMENDATION}

The results of this study has a number of implications for both research works related to the assessment of tourists' satisfaction, and also for practitioners and managers of natural sites and recreation centres. This study provides an understanding of how visitors' satisfaction with the site attributes (services and facilities) influences their levels of satisfaction with their experiences at Agodi Parks and Gardens. Overall visitor's experience in natural sites and recreation parks is highly dependent on their satisfaction with the site-specific elements. Specifically, the services provided by the staff and the facilities available for tourist/visitor at the park seem to be the most important attributes increasing visitors' levels of satisfaction with site attributes, while the quality of the activities provided at the site was the most important attribute influencing overall satisfaction with experiences at the park. This is not surprising given the limited variety of activities provided at Agodi Park and Gardens, most of the activities are the main reason of visitation. This further strengthens the theoretical understanding of the link between satisfaction and service quality. Lee et al. (2004) argued that quality refers to the judgements of services offered by tourists, such as evaluation of the toilet and campground facilities, which affects their satisfaction with the experience.

Regarding the site attributes, the management of the park might want to focus on those attributes which were deemed by respondents to be less than satisfactory. For example, the Zoological garden. Respondents may be generally satisfied with the site attributes, their levels of satisfaction with the recreational activities provided at the site was the lowest as proved by the multiple regression analysis carried out to test hypothesis designed for this work. The findings of this study concludes that the quality of services offered at Agodi Park and Gardens has a great impact on the overall visitors' satisfaction. This study confirmed that service quality has a direct relationship with visitors' satisfaction. It was also discovered that tourists in Agodi Park and Gardens are moderately satisfied with the level of tourism services.

However, these results recommends that visitors' satisfaction can be boosted by raising the standard of service quality throughout the destinations' attractions, facilities and modes of accessibility. The Parks' management should 
upgrade the zoological garden to meet up with International standard. Also, varieties of wild animal species should be kept at the zoo so as to increase tourists' patronage and satisfaction.

\section{SOURCES OF FUNDING}

This research received no specific grant from any funding agency in the public, commercial, or not-for-profit sectors.

\section{CONFLICT OF INTEREST}

The author have declared that no competing interests exist.

\section{ACKNOWLEDGMENT}

None.

\section{REFERENCES}

[1] Adedeji J.A., \& Fadamiro J.A (2014) Ecotourism Landscapes: An Editorial, American Journal of Tourism Management, Vol. 3 No. 1A, 2014, pp. 0-0. Doi: 10.5923/s.tourism.201401.

[2] Alarape, A.A, Yager, G.O \& Salman K.K (2015). Assessment of Tourist Satisfaction and Perception in Markudi Zoological Garden, Benue State, Nigeria. JFEWR Publications, Vol 7, No. 1, 2015, pp 2.

[3] Chandler, J.A., \& Costello, C.A. (2002). A profile of visitors to heritage tourism destination in East Tennessee according to Plog"s lifestyle and activity level preference model. Journal of Travel Research, 41, 161-166.

[4] Chen, C. \& Chen, F. (2010). Experience quality, perceived value, satisfaction and behavioral intentions for heritage tourists. Tourism Management, 31, 29-35.

[5] Chen, C. \& Tsai, D. (2007). How destination image and evaluative factors affect behavioral intentions. Tourism Management. 28 (4). Pp. 1115-1122.

[6] Choi, T. \& Chu, R. (2001). Determining of hotel guests" satisfaction and repeat patronage in the Hong Kong hotel industry. International Journal of Hospitality Management. 20. 277-97.

[7] Dmitrovic, T., Cvelbar, K. L., Kolar, T., Brencic, M. M., Ograjensek, I., Zabkar, V. (2009), 'Conceptualization tourist satisfaction at the destination level”, International Journal of Culture, Tourism and Hospitality Research 3(2): 116-126.

[8] Gursoy, D., McCleary, K. W. \& Lepsito, L. R. (2003). Segmenting dissatisfied restaurant customers based on their complaining response styles. Journal of Food Service Business Research, 6 (1). 25-44

[9] Kozak, M., \& Rimmington, M. (2000). Tourist satisfaction with Mallorca, Spain, as an off-season holiday destination. Journal of Travel and Tourism. Vol 9 No 3. 162-170

[10] Kukoyi, I.A (2013). Evaluation of Ikogosi warm spring as a Geotourism site in Ekiti state, Nigeria. European Journal of Hospitality and Tourism Research Vol 1, No 3, pp. 1-9

[11] Lee, J., Graefe, A.R., \& Burns, R.C. (2004). Service quality, satisfaction, and behavioral intention among forest visitors. Journal of Travel \& Tourism Marketing, 17(1). 73-82.

[12] Neal, J.D., \& Gursoy, D. (2008). A multifaceted analysis of tourism satisfaction. Journal of Travel Research, 4. 53-62.

[13] Omonona, A. O \& Kayode I. B. (2011). Ecotourism: implications on human and wildlife health 1st ed. Ibadan University press Publishing House, University of Ibadan, Nigeria: 1-130

[14] Opperman, M. (2000). Tourism destination loyalty. Journal of Travel Research, 39(1): 78-84.

[15] Pawitra, T. A. \& Tan, K. C. (2003), "Tourist satisfaction in Singapore- a perspective from Indonesian.

[16] Pizam, A., Neumann, Y. \& Reichel, A. (1978), "Dimensions of tourist satisfaction with a Research, 38, 260-269.

[17] Robinson, T., \& Gammon, S. (2004). A question of primary and secondary motives: revisiting and reapplying the sport tourism framework. Journal of Sport Tourism, 9, 221-233 
[18] Suleyman, F, Hulusi, D. \& Engin U. (2011). Tourists' perception and satisfaction of shopping in Alanya Region: A comparative Analysis of Different Nationalities. 7th International Strategic Management Conference. Vol. 24 pg. 5

[19] Uloko, I. J \& Iwar, M. I. (2011). Impact of Makurdi Zoological Garden and Menatarium on Conservation education in Benue State: Journal of Research in forestry, wildlife and Environment 3.2.

[20] Whipple, T. W., \& Thach, S.V. (1988). Group tour management: does good service produce satisfied customers? Journal of Travel Research, 28 (Fall), 16-21.

[21] Yoon, Y., \& Uysal, M. (2005). An examination of the effects of motivation and satisfaction on destination loyalty: A structural model. Tourism Management, 26(1), 45-56.

[22] Yooshik, Y. A., \& Muzaffer, U. B. (2003). An Examination of the Effects of Motivation and Satisfaction on Destination Loyalty: A Structural Model. Tourism Management, 26 (2005), 45-56. 